$$
\begin{array}{ccccccc}
\text { L } & \text { E } & \text { T } & \text { u } & \text { v } & \text { O } & \text { s } \\
\hline \text { ARCHEOlogija } & 46
\end{array}
$$


Lietuvos istorijos institutas

\begin{tabular}{llllllll}
$\mathrm{L}$ & $\mathrm{I}$ & $\mathrm{E}$ & $\mathrm{T}$ & $\mathrm{U}$ & $\mathrm{V}$ & $\mathrm{O}$ & $\mathrm{S}$ \\
\hline
\end{tabular}

ARCHEOlogija 46 


\section{Leidybą finansavo}

\section{LIETUVOS MOKSLO TARYBA}

PAGAL VALSTYBINĘ LITUANISTINIŲ TYRIMŲ IR SKLAIDOS 2016-2024 METŲ PROGRAMĄ

(Finansavimo sutarties numeris S-LIP-19-4)

\section{Redaktorių kolegija / Editorial board:}

Atsakingoji redaktorė / Editor-in-chief dr. Agnè Čivilytė (Lietuvos istorijos institutas, Vilnius / Lithuanian Institute of History, Vilnius)

Atsakingosios redaktorès pavaduotoja / Assistant Editor dr. Elena Pranckènaitè (Lietuvos istorijos institutas, Vilnius / Lithuanian Institute of History, Vilnius)

Dr. Laurynas Kurila (Lietuvos istorijos institutas, Vilnius / Lithuanian Institute of History, Vilnius)

Dr. Valdis Bērziņš (Latvijos universitetas, Latvijos istorijos institutas, Ryga / University of Latvia, Institute of Latvian History, Riga)

Habil. dr. Anna Bitner-Wróblewska (Valstybinis archeologijos muziejus Varšuvoje, Lenkija / State Archaeological Museum in Warsaw, Poland)

Dr. Christoph Jahn (Baltijos ir Skandinavijos archeologijos centras, Šlèzvigas, Vokietija / Center for Baltic and Scandinavian Archaeology, Schleswig, Germany)

Prof. dr. Rimantas Jankauskas (Vilniaus universitetas, Lietuva / Vilnius University, Lithuania)

Akad. prof. dr. Eugenijus Jovaiša (Lietuvos mokslu akademija, Vilnius / Lithuanian Academy of Sciences, Vilnius)

Habil. dr. Bartosz Kontny (Varšuvos universitetas, Archeologijos fakultetas, Lenkija / Faculty of Archaeology, University of Warsaw, Poland)

Prof. dr. Valter Lang (Tartu universitetas, Estija / University of Tartu, Estonia)

Doc. dr. Algimantas Merkevičius (Vilniaus universitetas, Lietuva / Vilnius University, Lithuania)

Habil. dr. Tomasz Nowakiewicz (Varšuvos universitetas, Archeologijos fakultetas, Lenkija / Faculty of Archaeology, University of Warsaw, Poland)
Habil. dr. Grzegorz Osipowicz (Mikalojaus Koperniko universitetas, Torunè, Lenkija / Nicolaus Copernicus University, Toruń, Poland)

Dr. Gytis Piličiauskas (Lietuvos istorijos institutas, Vilnius / Lithuanian Institute of History, Vilnius)

Dr. Eve Rannamäe (Tartu universtitetas, Estija / University of Tartu, Estonia)

Dr. Andra Simniškyte (Lietuvos istorijos institutas, Vilnius / Lithuanian Institute of History, Vilnius)

Dr. Roberts Spirgis (Latvijos universitetas, Latvijos istorijos institutas, Ryga / University of Latvia, Institute of Latvian History, Riga)

Dr. Eugenijus Svetikas (Lietuvos istorijos institutas, Vilnius / Lithuanian Institute of History, Vilnius)

Dr. Andris Šnē (Latvijos universitetas, Ryga / University of Latvia, Riga)

Doc. dr. Gintautas Zabiela (Klaipédos universitetas, Lietuva / Klaipeda University, Lithuania)

Prof. dr. Šarūnas Milišauskas (Niujorko valstijos Bafalo universitetas, JAV / New York State University at Buffalo, USA)

Prof. dr. Timothy Chevral (Niujorko valstijos Bafalo universitetas, JAV / New York State University at Buffalo, USA)

Prof. dr. Johan Ling (Gioteborgo universitetas, Švedija / University of Gothenburg, Sweden)

Sekretorè / Secretary Dovilè Urbonavičiūtè-Jankauskienė

Redakcijos adresas / Editorial Board address:

Lietuvos istorijos institutas, Archeologijos skyrius

Kražių g. 5, LT-01108 Vilnius

Tel. (+370) 5 2614935, fax (+370) 52611433

e-mail: lietuvosarcheologija@gmail.com;

civilytea@gmail.com

\section{Žurnalas registruotas: EBSCO Publishing: Central and Eastern European Academic Source European Reference Index for the Humanities and Social Sciences (ERIH PLUS)}




\section{TURINYS / CONTENT}

Agnè Čivilytè

Agnè Čivilytè

Jonas Beran

Gabrielè Gudaitienè

Andreas Kotula, Henny Piezonka, Thomas Terberger

Vygandas Juodagalvis

Eglè Šatavičè

Grzegorz Osipowicz, Justyna Orłowska, Gytis Piličiauskas, Giedrẻ Piličiauskienė, Mariusz Bosiak

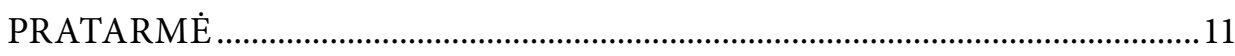

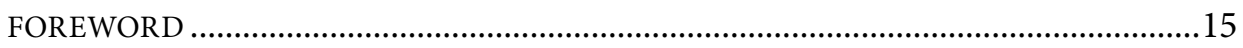

RUDENS POPIETĖ SU RIMUTE RIMANTIENE _.............................................19

AUTUMN AFTERNOON WITH RIMUTE் RIMANTIENĖ

GREETINGS FROM OLD CENTRAL-EASTERN GERMANY:

MEMORIES OF INTERESTING TIMES .27

LINKĖJIMAI IŠ PIETRYČIŲ VOKIETIJOS: PRISIMINIMAI APIE ĮDOMIUS LAIKUS

\section{STRAIPSNIAI / ARTICLES}

EIGULIAI, ONE OF RIMUTE் RIMANTIENĖ'S FIRST EXCAVATIONS A REVISED INTERPRETATION .33

EIGULIAI - VIENA PIRMŲJŲ RIMUTĖS RIMANTIENĖS KASINĖJIMŲ VIETŲ.

NAUJA INTERPRETACIJA

THE MESOLITHIC CEMETERY OF GROß FREDENWALDE (NORTH-EASTERN GERMANY) AND ITS CULTURAL AFFILIATIONS.......65 GROS FREDENVALDE (ŠIAURĖS RYTŲ VOKIETIJA) MEZOLITO LAIKOTARPIO KAPINYNAS IR JO KULTÜRINĖS SĄSAJOS .83

AKMENINIAI GLUDINTI KIRVIAI LIETUVOJE. TIPOLOGIJOS IR TERMINOLOGIJOS PROBLEMOS .85 GROUND STONE AXES IN LITHUANIA. PROBLEMS OF TYPOLOGY AND TERMINOLOGY 108

NEOLITHIC SOCIETIES AND THEIR POTTERY IN SOUTH-EASTERN LITHUANIA 111 NEOLITO BENDRUOMENĖS IR JỤ KERAMIKA PIETRYČIỤ LIETUVOJE. 142

OSSEOUS POINTS AND HARPOON HEADS FROM ŠVENTOJI SUBNEOLITHIC SITES, COASTAL LITHUANIA. FIRST TRACEOLOGICAL INSIGHT INTO THE WAY THEY WERE PRODUCED AND USED 147

KAULINIAI ANTGALIAI IR ŽEBERKLAI LIETUVOS PAJÜRIO ŠVENTOSIOS SUBNEOLITINĖSE GYVENVIETĖSE: GAMYBA IR NAUDOJIMAS PIRMU巳JŲ TRASOLOGINIŲ TYRIMỤ DUOMENIMIS 168 
Sławomir Kadrow

Frédéric Surmely

Rokas Vengalis, Jonas Volungevičius, Gintautas Vèlius, Albinas Kuncevičius, Justina Poškienè, Regina Prapiestienè

Andra Simniškytè

Inga Merkyte்

Rokas Vengalis
MACRO AND MICRO SCALE NEOLITHISATION PROCESSES IN SOUTH-EASTERN POLAND AGAINST THE BACKGROUND OF CENTRAL-EASTERN EUROPE 171

PIETRYČIŲ LENKIJOS NEOLITIZACIJOS PROCESAI MIKRO- IR MAKROLYGMENIMIS VIDURIO IR RYTŲ EUROPOS KONTEKSTE 187

CHARACTERIZATION OF TERTIARY FLINTS BY GEOCHEMISTRY: APPLICATION TO THE FRENCH TERRITORY.

TERCIARO TITNAGO PRANCÜZIJOS TERITORIJOJE CHARAKTERIZAVIMAS NAUDOJANT GEOCHEMINI METODĄ

ŽMOGUS PRIEŠ GAMTĄ: RELJEFO TRANSFORMAVIMAS İRENGIANT XIII-XIV A. KERNAVÉS PILI IR JO SUKELTI EROZINIAI PROCESAI ....... 207 MAN AGAINST NATURE: THE TRANSFORMATION OF THE RELIEF DURING THE CONSTRUCTION OF KERNAVĖ CASTLE IN THE $13^{\mathrm{TH}}-14^{\mathrm{TH}}$ CENTURIES AND THE EROSIONAL PROCESSES IT CREATED 248

KUPIŠKIO (AUKŠTUPĖNŲ) PILIAKALNIS: TEORINĖS PRIELAIDOS

IR TYRIMŲ REZULTATAI .255

HILLFORT OF KUPIŠKIS (AUKŠTUPĖNAI): THEORETICAL ASSUMPTIONS AND INVESTIGATION RESULTS 284

\section{KITAIP APIE ARCHEOLOGIJA /} ALTERNATIVE PERCEPTIONS OF ARCHAEOLOGY

Šarūnas Radvilavičius

KELIAUTOJO LAIKU UŽRAŠAI. 289

THE NOTEBOOK OF TIME TRAVELLER

\section{DISKUSIJOS / DISCUSSIONS}

STUDIES OF ANCIENT DNA. THE RACE FOR THE ULTIMATE ANSWER .293

SENOVĖS DNR TYRIMAI: KARŠTLIGIŠKOS ATSAKYMŲ PAIEŠKOS

\section{RECENZIJOS / REVIEWS}

ALGIMANTAS MERKEVIČIUS (SUD.), 2018. ANKSTYVOJO METALŲ LAIKOTARPIO GYVENVIETÉS LIETUVOJE (SETTLEMENTS OF EARLY METAL PERIOD IN LITHUANIA). 305

INFORMACIJA APIE PROJEKTUS / INFORMATION ABOUT THE PROJECTS 309

AUTORIŲ DĖMESIUI. 327 GUIDELINES FOR AUTHORS 


\title{
CHARACTERIZATION OF TERTIARY FLINTS BY GEOCHEMISTRY: APPLICATION TO THE FRENCH TERRITORY
}

\author{
FRÉDÉRIC SURMELY
}

Service régional de l'archéologie d'Auvergne-Rhône-Alpes and Unité Mixte de Recherches CNRS n 6042, GEOLAB - 4 rue Pascal, 63000, Clermont-Ferrand, France, e-mail: surmely.frederic@wanadoo.fr

In present-day France, tertiary flints have played an important part in the supply of prehistoric populations, due to their abundance, quality and presence in areas without marine flint. From the Upper Paleolithic until the end of the use of flint, they were transported over far distances, especially in the center of the Central Massif.

In this article the geochemical method is preferred for attributing of precise geographical origin to an archaeological artifact. To form the geological repository, a very large geographical field was taken, encompassing a large part of France, from the Marne county to the Gard county, and most of the major French sedimentary basins (Bassin Parisien, Cantal, Gard). The archaeological corpus includes pieces from sites of the Upper Paleolithic and the Epipaleolithic of Auvergne. The geochemical study does not provide a comprehensive answer to the question of the geographical origin of tertiary flints, but nevertheless allows for certain and significant advances in knowledge.

Keywords: Flint raw materials, Palaeolithic age, Magdalenian, Raw materials, Geochemistry.

Dabartinès Prancūzijos teritorijoje terciaro periode susiformavęs titnagas buvo itin svarbi žaliava priešistorinems populiacijoms dèl gausos, kokybès ir prieinamumo vietovése, kuriose nèra jürinès kilmès titnago išteklių. Nuo vélyvojo paleolito iki pat titnago naudojimo pabaigos terciaro titnago žaliava buvo gabenama ilgus atstumus, ypač vidurineje Centrinio Masyvo dalyje.

Šiame straipsnyje, siekiant archeologiniams radiniams priskirti tiksliq žaliavos, iš kurios jie pagaminti, geografinę kilmę, pirmenybe teikta geocheminiam metodui. Tyrimui panaudoti geologiniu meginiu analizés duomenys iš plataus geografinio regiono, apimančio didelę dali Prancüzijos - nuo Marnos iki Garo departamento, bei dauguma didžiujų Prancüzijos sedimentaciniu baseinu - Paryžiaus baseina ir baseinus Kantalio bei Garo departamentuose. Archeologiniu duomenu rinkinys sudarytas tiriant méginius iš Overnès regiono vèlyvojo paleolito ir epipaleolito archeologiniu vietoviu. Geochemine analizè nesuteikè išsamiu atsakymu, kuriais remiantis bütu galima nustatyti geografinę terciaro titnago žaliavos kilmę, tačiau padejo praplèsti žinias tam tikrais svarbiais klausimais.

Reikšminiai žodžiai: titnago žaliava, paleolitas, Madlenas, žaliava, geochemija.

\section{THE USE OF TERTIARY FLINT IN PREHISTORIC TIMES}

In the territory of present-day France, Tertiary flints were important sources of raw materials for prehistoric populations because of their abundance, their quality (Surmely, Murat 2003), and their presence in sectors devoid of marine flint.
Flint outcrops were exploited since the early Palaeolithic. From the Upper Palaeolithic and until the end of the use of flint, they were the subject of long distance transport, like other types of marine flint, such as the flint of the Lower Turonian and the Upper Turonian of Berry and Touraine. This is the case with allochthonous Tertiary flint brought to the archaeological sites of 
Val d'Allier (Protomagdalenian and especially Middle Magdalenian; Surmely 2008).

In the Neolithic, long-distance distribution mainly concerned specialized products produced in large quantities, sometimes from mines. The bestdocumented cases are those of Jablines and Flins for polished axes (Bostyn, Lanchon 1992; Giligny, Bostyn 2016). At Taussac, there is another site with galleries used to extract Tertiary flint nodules, but the nature of the production remains hypothetical. The circulation of daggers at the end of the Neolithic is attested from a few production centers located in the AptForcalquier basin (Renault 2006; Vaquer et al. 2006), Gard (Salinelles, Collorgues; Vaquer et al. 2006), and possibly Mur-de-Barrez (Vaquer et al. 2006).

In the majority of cases, Tertiary flint has been the subject of specific studies, which do not allow comparison with other 'competing' materials. When the different types of materials are put into perspective, a similar use of the various flints can be seen. This is especially the case with daggers from the late Neolithic era in north-western Europe (DelcourtVlaeminck 1998).

Macroscopic and microscopic examinations are insufficient to attribute a precise geographical origin to an archaeological artifact. In this article the geochemical method is preferred. To form the geological repository, we have taken a very large geographical field, encompassing a large part of France, from the Marne to the Gard, and most of the major French sedimentary basins (Parisien Basin, Cantal, Gard). The archaeological corpus includes pieces from sites of the Upper Paleolithic and the Epipaleolithic of Auvergne.

\section{THE MULTIPLICITY OF POTENTIAL SOURCES}

I will only speak here of intraformational silicifications, which excludes vein materials (of the opal-resinite type) and marine flint included in Tertiary age alterites. The materials are found in carbonate levels belonging to palustrine or lacustrine sedimentary basins whose ages range from the Middle Eocene (Lutetian) to the Upper Oligocene (Chattien). These basins are numerous in French territory and are found in many regions, but not in some ancient massifs like at the Massif Armoricain. Their size is very variable, ranging from a few or tens of square kilometres for the smallest (La Perche, Cher; Muides, Loir-et-Cher) to several hundred square kilometres with several levels of silicification such as the Aurillac/Mur-de-Barrez basin. The best documented are those of the eastern part of the Paris Basin, Étrelles (Haute-Saône; Cupillard et al. 1995), and Aurillac/Mur-de-Barrez (Cantal and Aveyron; Pasty et al. 1999; Surmely 2003).

\section{DESCRIPTION OF TERTIARY SILICIFICATIONS}

In the vast majority of cases, Tertiary flints come in the shape of platelets or large slabs of varying thickness and size, which can reach $80 \mathrm{~cm}$ in diameter and weigh more than $100 \mathrm{~kg}$, as in Taussac (Aveyron), or even form entire (soil) horizons. The cortex is usually thin, but sometimes there are incompletely silicified subcortical layers unsuitable for knapping. The texture can be very fine. They are generally opaque and the colours range from light beige to black, with a wide range of more or less dark browns. Zonations of colour and texture, in the form of ribbons, laminae, and breccias, are frequent and linked to the phenomena of stratification and/or desiccation and disturbance in shallow water environments (Lozouet 2012). Colour and structure vary greatly within the same horizon, or even the same nodule (Figs. 1-3). Some materials have a greasy, shiny appearance, which has earned them the vernacular name of 'resinites'. This particular texture is due to their formation in a marsh environment with vacuolar biological structures (old roots) filled with a halo of fibrous 

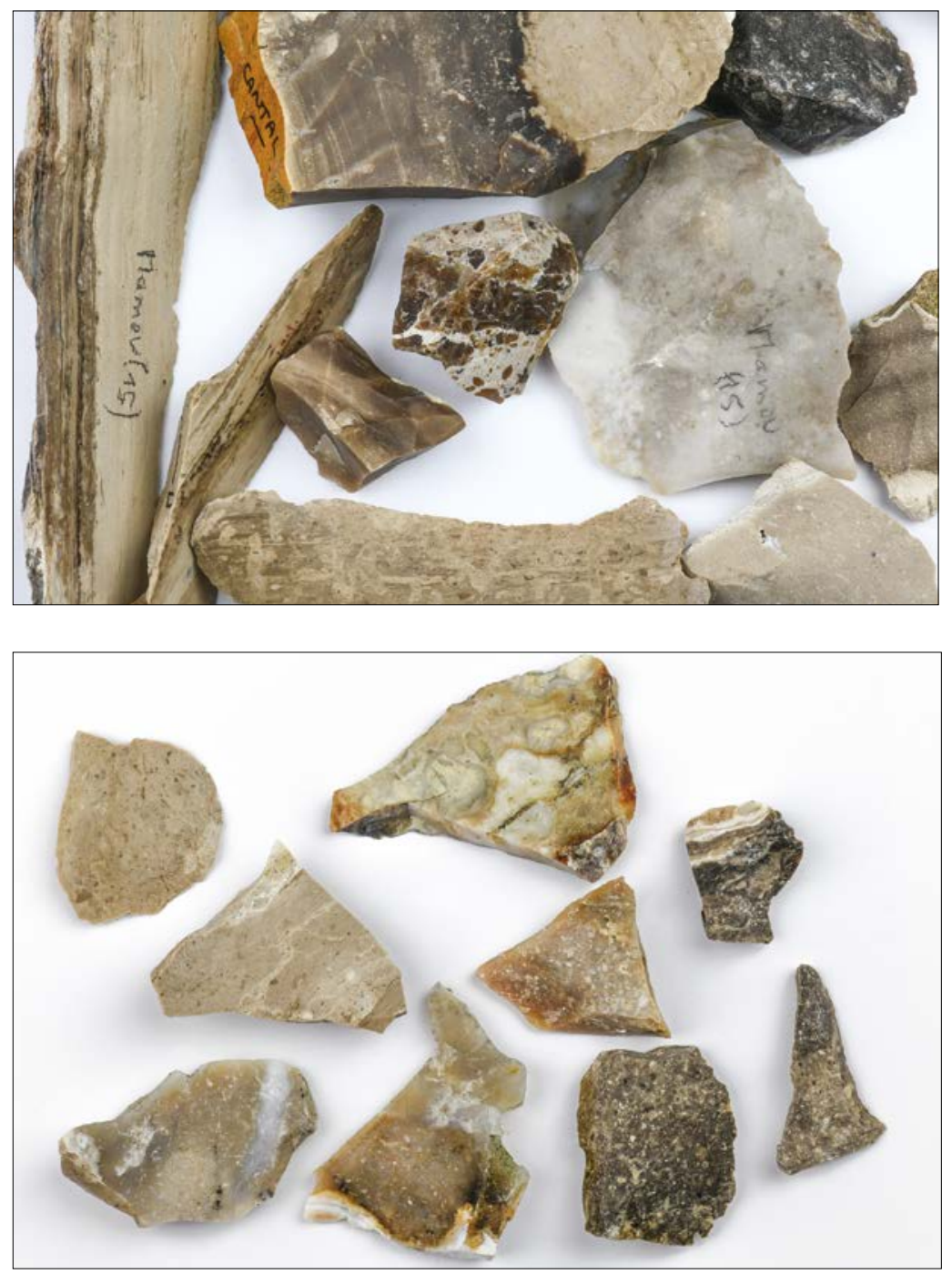

Fig. 1. Variability of Tertiary flint collected in the alluvium of a stream in the heart of the Aurillac / Mur-de-Barrez basin in Giou-deMamou. Photo by F. Surmely.

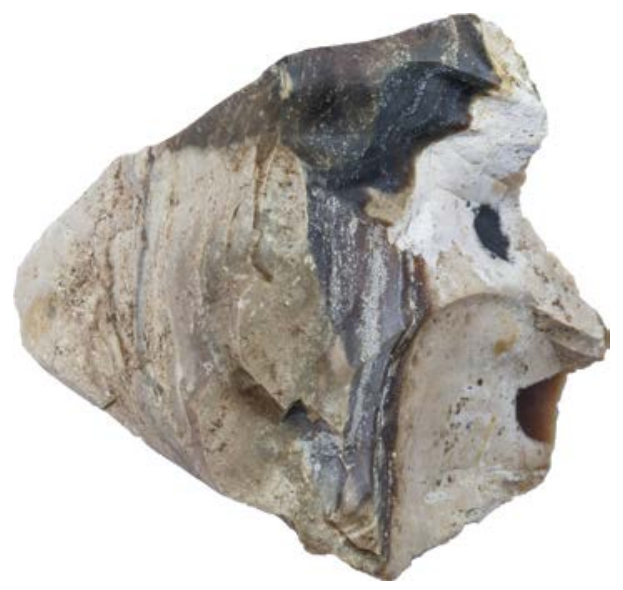

Fig. 2. Colour and texture variability in a nodule of Tertiary flint from Vézac (Cantal, Aurillac/Mur-de-Barrès basin). Photo by F. Surmely.

Fig. 3. Variability of silicifications collected at La Perche (Cher). Photo by F. Surmely. chalcedony and a quartz core (Barrier 1995). Translucent or brightly coloured silicifications are extremely rare. In this respect, the Lasmolineries sector, which offers very bright honey-yellow, rusty, red, greenish, and translucent white flint with colour gradations within the same block (Fig. 4), is an exception (Surmely 2003).

Fig. 4. Flint from the Lasmolineries Brook (Thiézac, Cantal) at the eastern tip of the Aurillac/Mur-de-Barrez basin. Photo by F. Surmely.

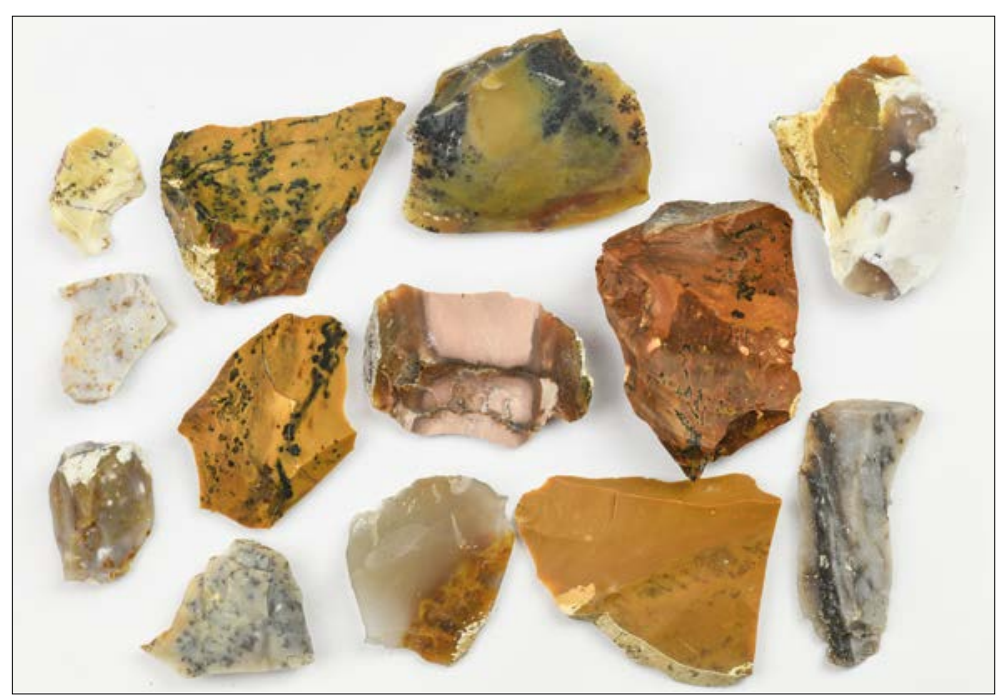




\section{CHARACTERIZATION OF MATERIALS AND DETERMINATION OF GEOGRAPHICAL ORIGIN BY MACROSCOPIC AND MICROSCOPIC EXAMINATIONS}

The diversity of the facies within the same sedimentary series, combined with the diagenetic similarity of the various Tertiary sedimentary basins are obstacles to determining the precise geographical origin of flint, especially since it could have been collected in different stratigraphic levels in the same place thanks to an escarpment or a natural cut or to its being found in a secondary position (alluvium, colluvium, decalcification clays, etc.).

\section{Macroscopic examination}

Macroscopic observation yields little information in terms of determining the origin of silicifications. Colour and texture are important criteria, but most of the different sedimentary basins deliver the same range. Hence the 'zoned' aspect, given as a characteristic of the flint in the valley of the Apt/Forcalquier basin or 'brecciated' at Collorgues (Gard), is found in many other materials from other sedimentary basins, such as those from Aurillac/ Mur-de-Barrez; Fig. 1). The finely banded structure, presented as peculiar to the flint of Salinelles (Gard),

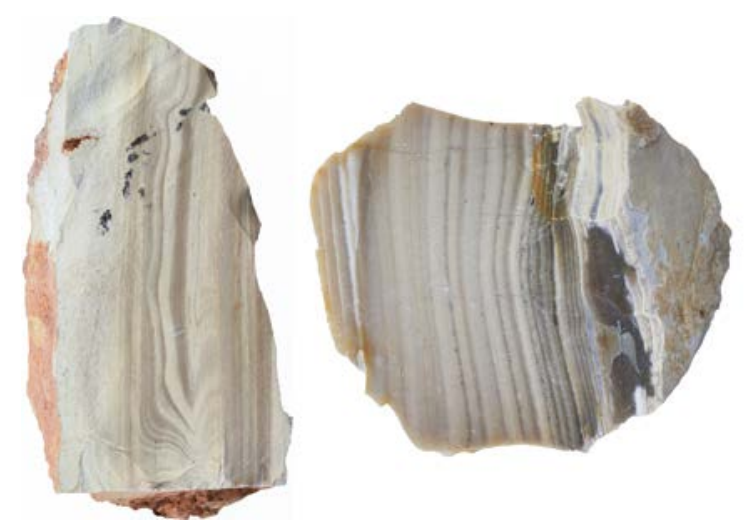

Fig. 5. Two finely streaked and similar-looking pieces of flint: on the left from Salinelles (Gard) and on the right from Orgnac (Ardèche). Photo by F. Surmely. is found in other places, notably at Montclus, another Upper Oligocene sedimentary basin $60 \mathrm{~km}$ away (Fig. 5). It is, however, possible to individualize the flint of the Limagne Oligocene, which displays a coarser texture and very frequently a banded appearance (Dufresne 1998; Surmely 2003).

\section{Microscopic examination}

Thin-section examination allows confirmation of the material's medium of origin on the basis of the nature of the bioclasts (charophytes, ostracods, gastropods, pellets, bitumen, etc.; Fig. 6) and their differentiation from marine silicifications. But determining the precise age is impossible due to the rather ubiquitous nature of small bioclasts. The microfacies makes it possible to distinguish diagenetic categories, linked in particular to a lacustrine or palustrine origin, but does not give any indication in terms of precise origin or even age. Tertiary sedimentary basins are characterized by sudden variations in facies, linked to the small size and thickness of the water coverings, which induce different facies a few meters away, both vertically (stratigraphically) and horizontally (lateral variation) (Barrier 1995; Cupillard et al. 1995).

So, macroscopic and microscopic examinations, although they give useful indications, are not sufficient to determine the geographical origin of the materials used for the prehistoric lithic industry.

\section{GEOCHEMICAL STUDY}

\section{Framework}

The present study is linked to the resumption of research on two important Magdalenian deposits in the central part of the Massif Central: Le Blot (HauteLoire) and Enval (Puy-de-Dôme).

The Enval site is located near important sources of Tertiary flint in Limagne d'Auvergne (Dufresne 1998; Surmely 2003). Despite this, prehistoric populations used fine-grained allochthonous Tertiary flint, which 


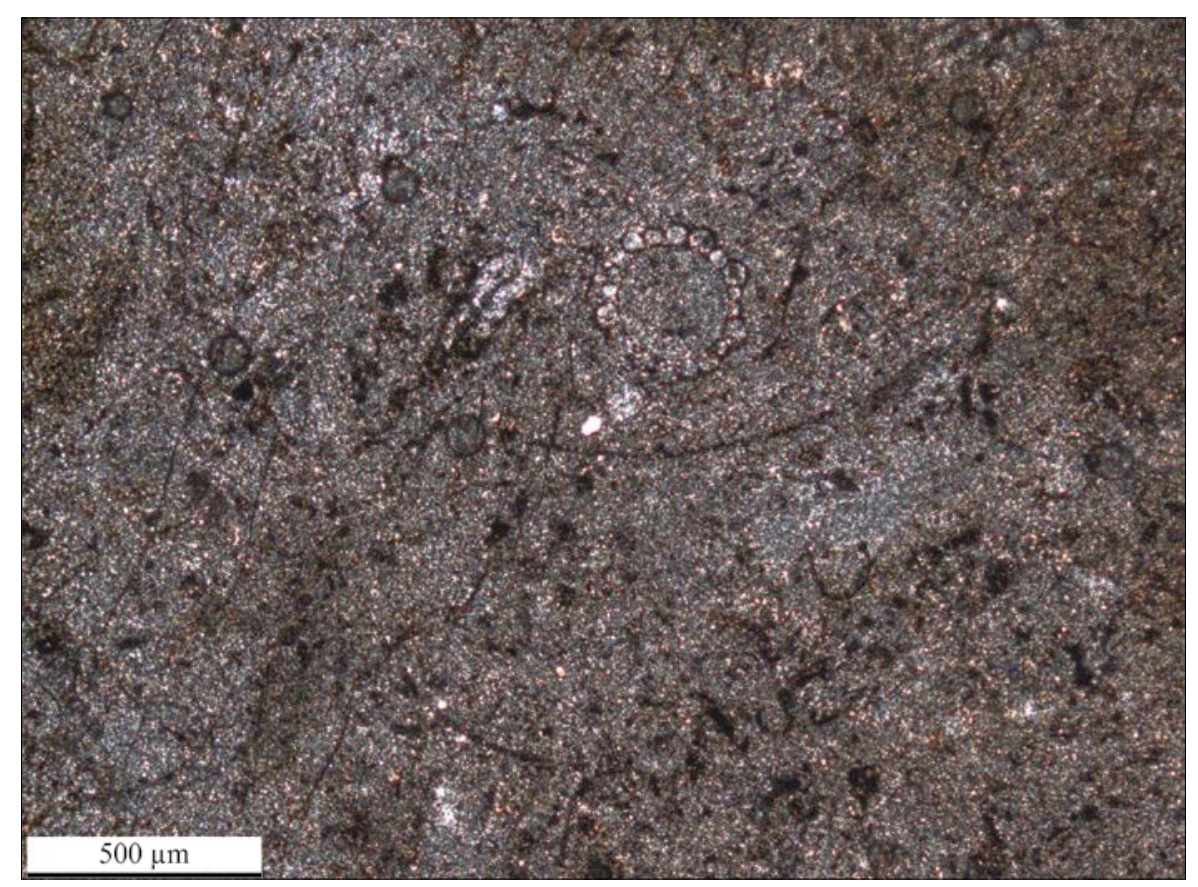

Fig. 6. A Characeae stem and an oogonium in a piece of Tertiary flint. Photo and analysis by P. Barrier.

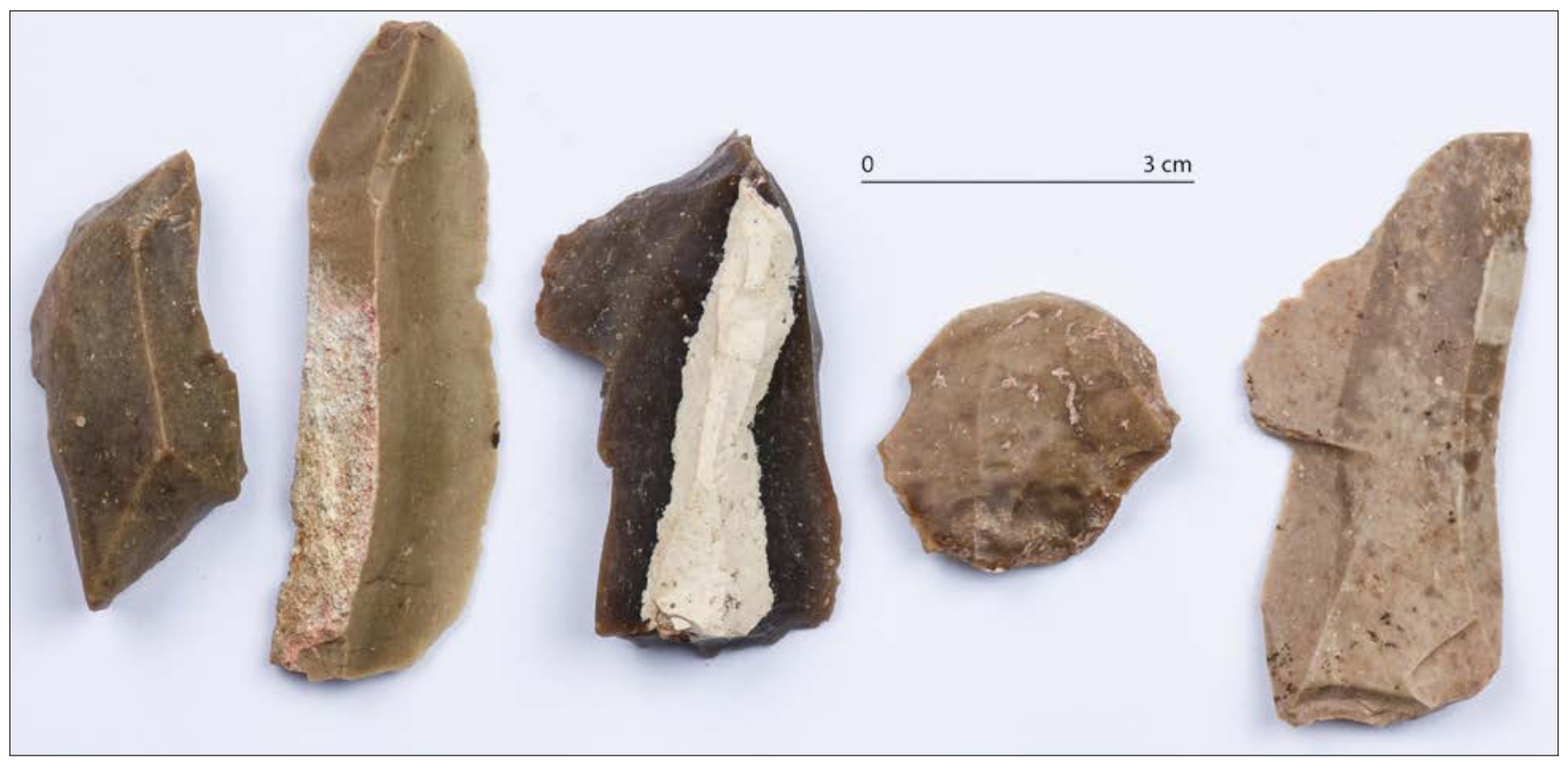

Fig. 7. Allochthonous Tertiary flint tools from the US80 level of the Enval-Moliard shelter (recent Middle Magdalenian; Vic-leComte, France; excavation by F. Surmely). Photo by F. Surmely.

is very different in appearance from local flint and amounted to as much as $4 \%$ of the total supply of flint (by weight), 15\% (by quantity of tools) (Figs. 7,8 ). This characteristic reflects the specific management and the distant origin of these materials compared to that of the local flint.

Le Blot is located in an area devoid of knappable flint. The closest flint sources are the Aurillac/ 


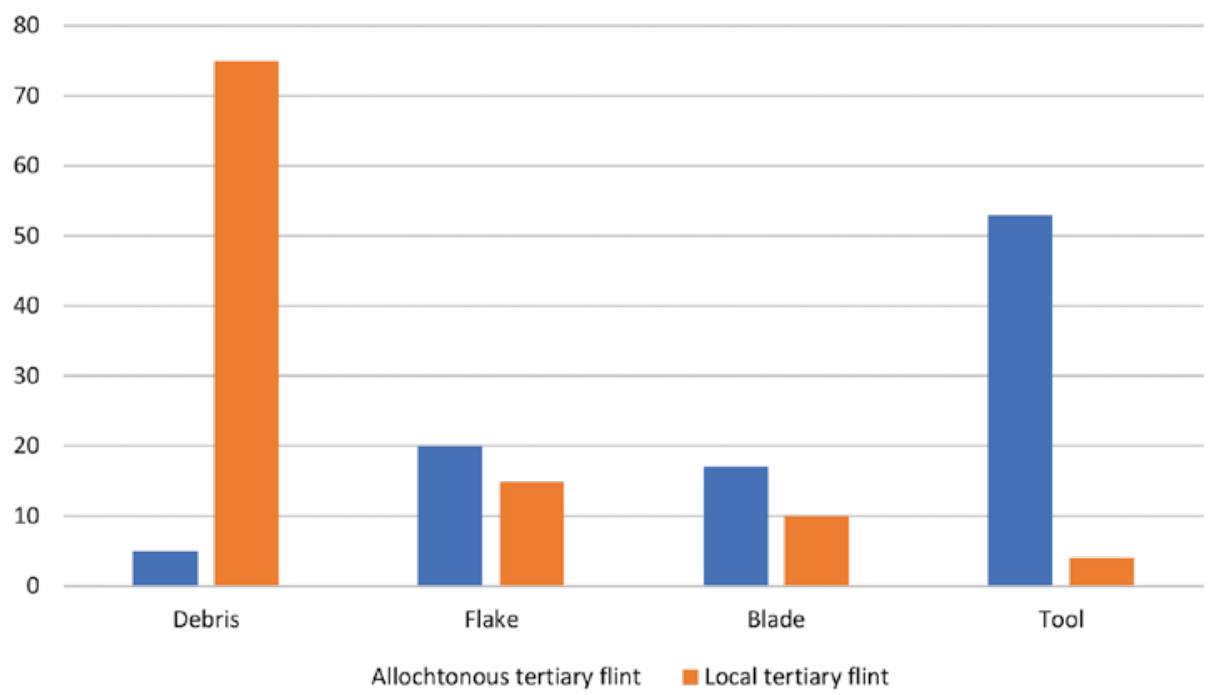

Fig. 8. Distribution of the main technological categories for local and allochthonous Tertiary flint, from the Magdalenian site of Enval. Table by F. Surmely.

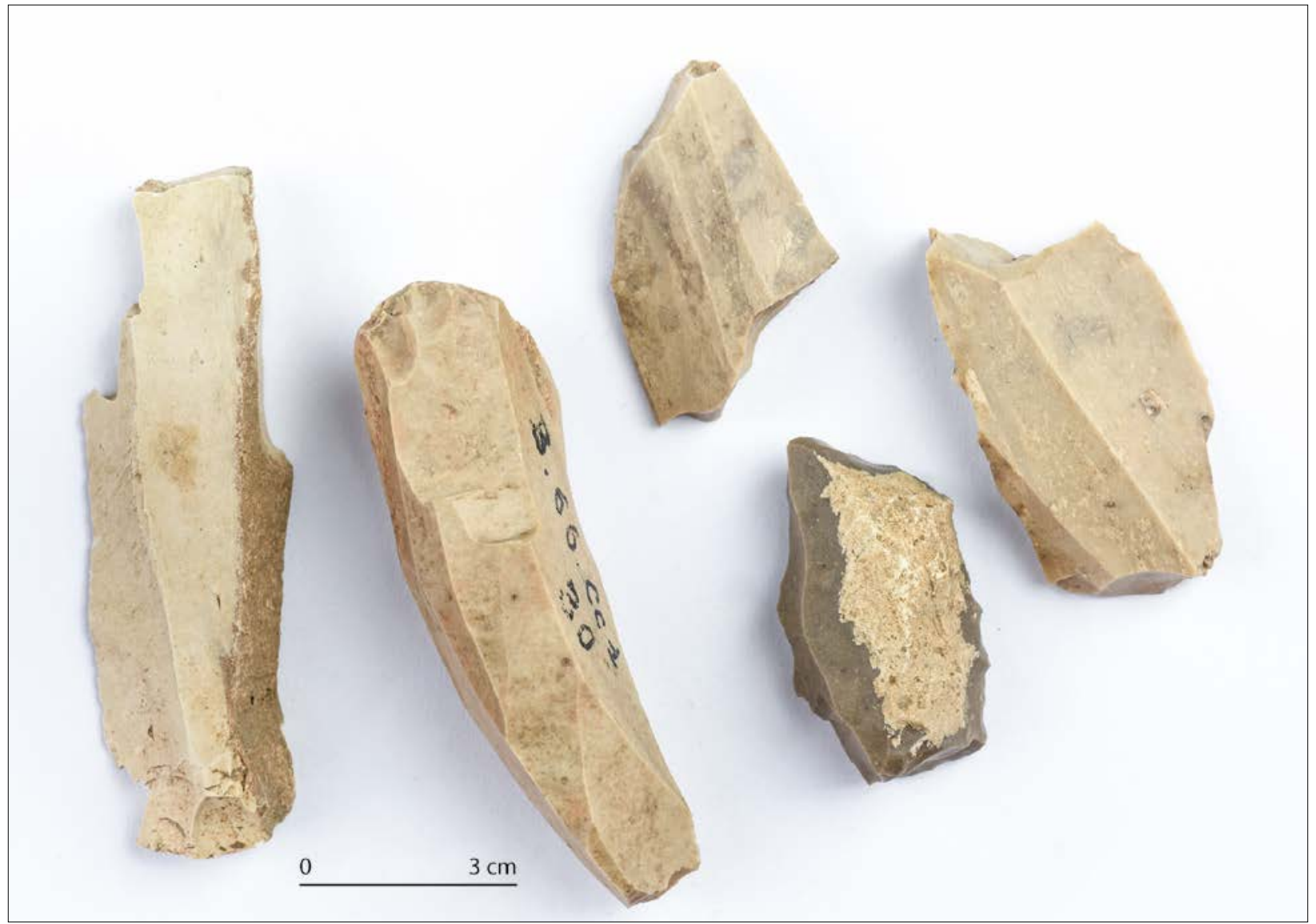

Fig. 9. Tertiary flint tools from the Le Blot site (Middle Magdalenian, excavation by Delporte). Photo by F. Surmely. 


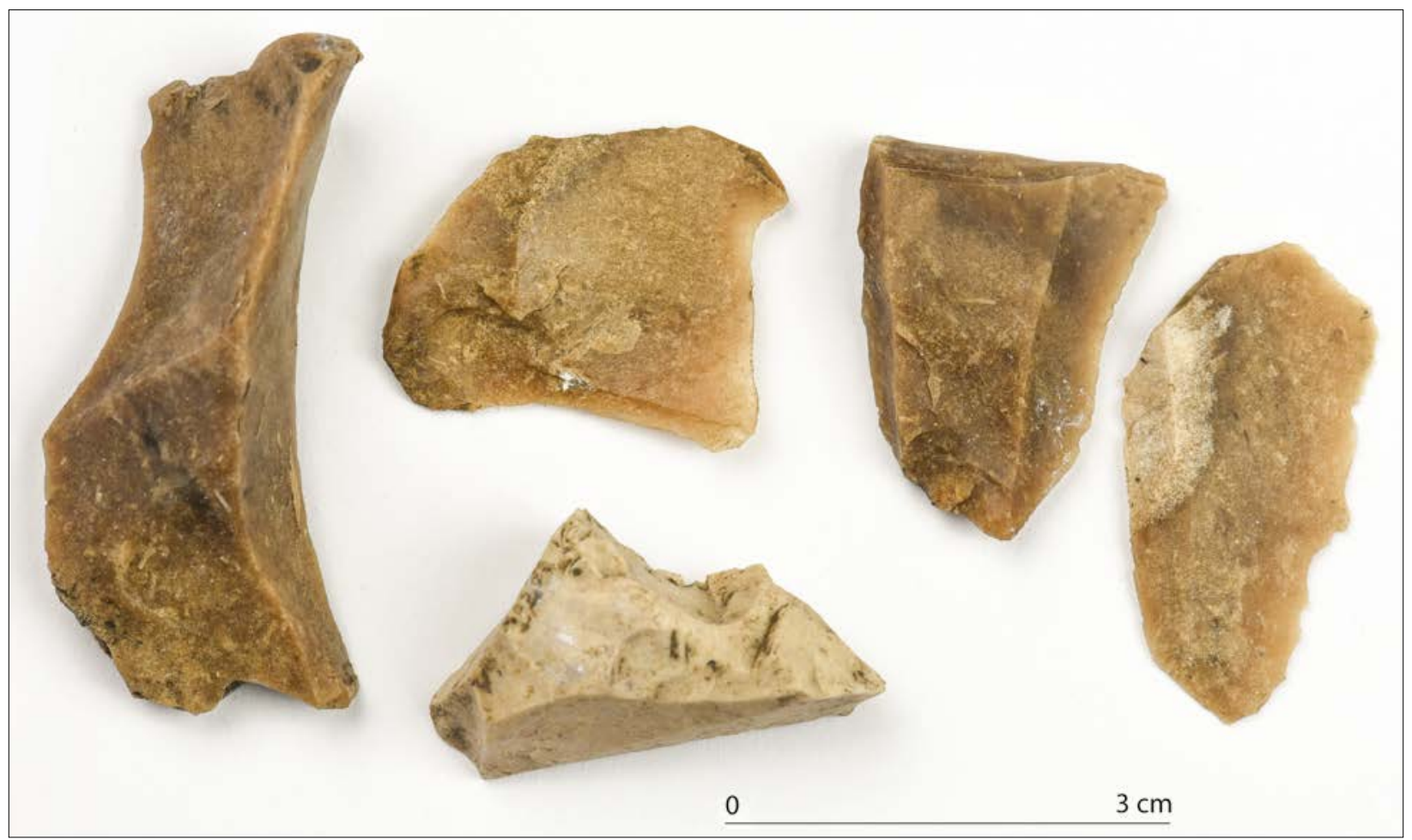

Fig. 10. Lithic industry in Tertiary flint from Les Bughes site (Azilien, La Tour d'Auvergne; excavation by Surmely). Photo by F. Surmely.

Mur-de-Barrez, Malzieu, and Limagne d'Auvergne basins. Tertiary flint represents an important part of the supply for the Magdalenian populations, i.e. more than $40 \%$ by weight of the lithic pieces found (Fig. 9). It is an exclusively fine-grained flint, different in appearance from Limagne flint, which must therefore be excluded as a possible provenance.

To these two Magdalenian sites have been added samples from various Upper Palaeolithic and postPalaeolithic sites from the central part of the Massif Central such as Le Sire (Mirefleurs, Puy-de-Dôme, Early Gravettian), La Bade (Collandres, Cantal, Magdalenian), Thônes (Grandeyrolles, Puy-de-Dôme, Magdalenian), Les Bughes (la Tour d'Auvergne, Puyde-Dôme, Epipalaeolithic; Fig. 10), and Le Croizet (Brioude, Haute-Loire, probably Magdalenian).

Finally, the question, recently asked by M. Remirecourt and J. Vaquer, about the characterization of the production of Neolithic flint mining in Taussac at the southern tip of the Aurillac/ Mur-de-Barrez basin, was considered (Surmely, Santallier 2003; Remirecourt, Vaquer 2017).

\section{Protocol and methodology}

Trace element geochemistry is an analytical method that reveals the chemical signature of rocks and their possible specificity. It is applied to all types of rocks, considering that rocks from the same sedimentary basin, sector, or stratigraphic level may have specificities related to their diagenesis. This method has been applied to Tertiary flint for about twenty years (Dufresne 1999; Blet et al. 2000; Giez 2001; Bressy 2002; 2006). But the studies focused on a reduced number of geological samples, ranging from 18 to 40 . In the case of Dufresne, the materials under consideration came from three sectors, Limagne, Brie, and Cantal. Bressy (2006) mainly focused on considering the sedimentary basins of south-eastern 


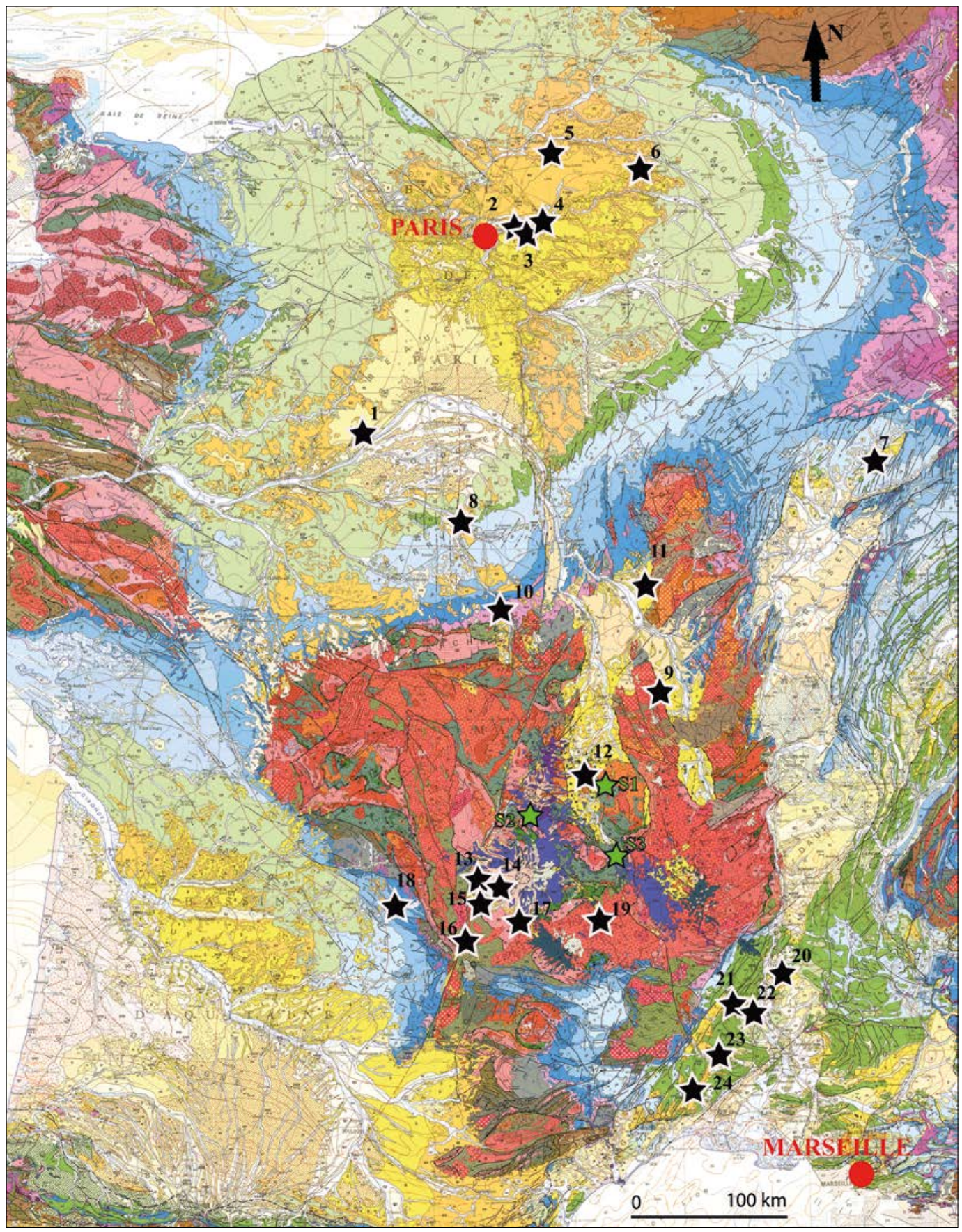

Fig. 11. Situation map of materials and artefacts analysed in this study. Drawing by F. Surmely.

Tertiary flint outcrops

1. Muides (Loir-et-Cher); 2-4. Montry-sur-Brie, Sauzy en Brie, Jablines, Lesches, Bouleurs, Couilly (Seine-et-Marne); 5. Oise; 6. Romigny (Marne); 7. Étrelles (Jura); 8. Foëcy (Cher); 9. La Pacaudière (Loire); 10. La Perche (Cher); 11. Sauvigny-les-Bois (Nièvre); 12. Busséol (Puy-de-Dôme); 13. vallée de la Doire (Cantal); 14. Polminhac (Cantal); 15. Arpajon, Saint-Simon, Yolet (Cantal); 16. Montmurat (Cantal); 17. Taussac (Aveyron); 18. Puy d'Issolud-Vayrac (Lot); 19. Saint-Léger-du-Malzieu (Lozère); 20. Grignan (Drôme); 21. Orgnac (Ardèche); 22. Montclus (Gard); 23. Collorgues (Gard); 24. Salinelles (Gard).

\section{Archaeological sites}

S1. Enval (Vic-le-Comte, Puy-de-Dôme); S2. Les Bughes (La-Tour-d’Auvergne, Puy-de-Dôme); S3. Le Blot (Cerzat, Haute-Loire). 


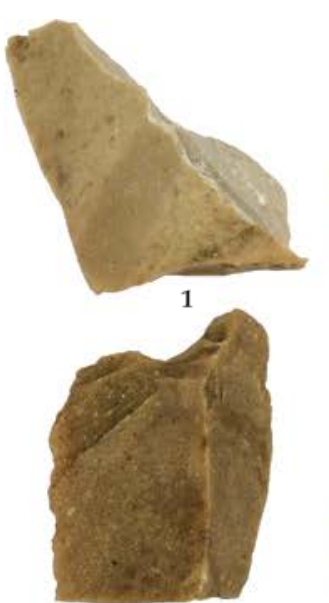

6

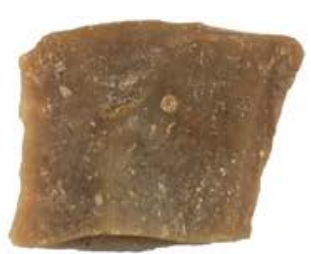

11
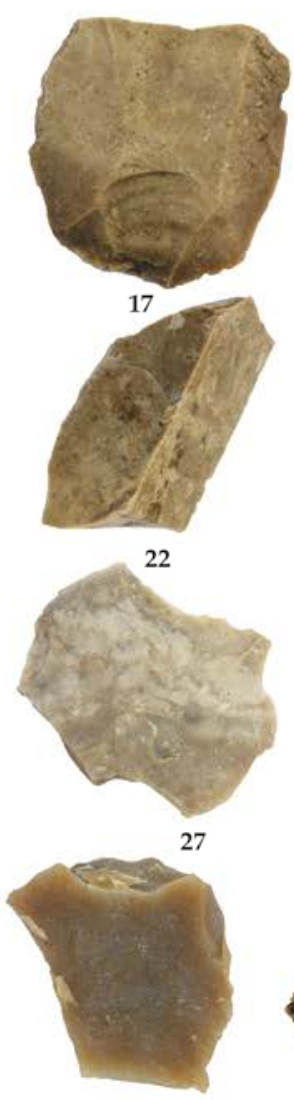

32
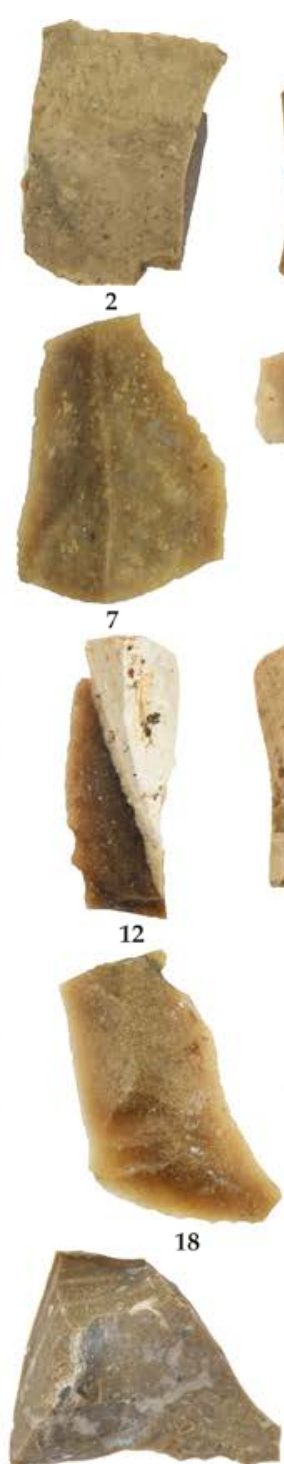

23
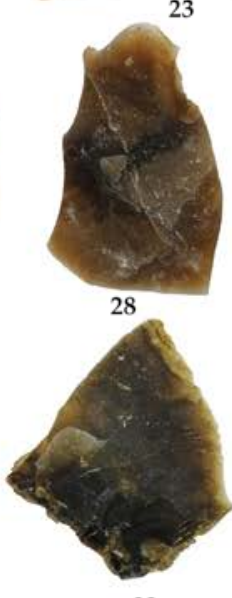

33

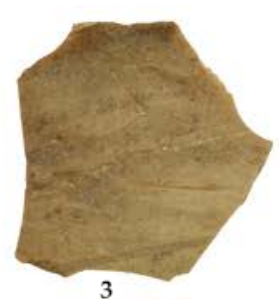

3

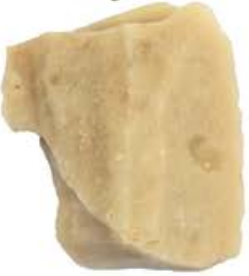

8

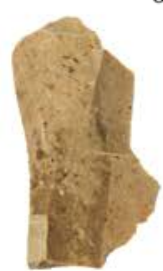

13
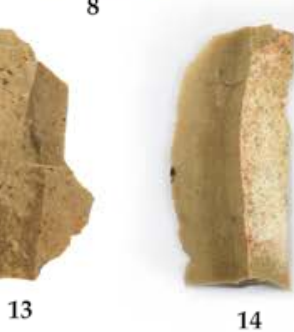

14

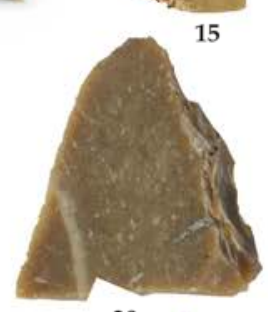

19

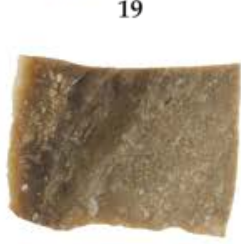

24

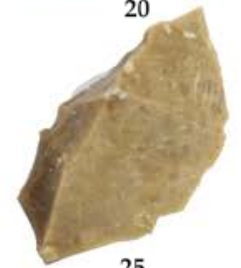

25

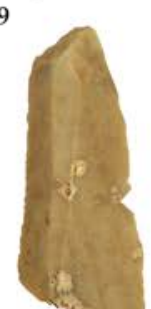

5

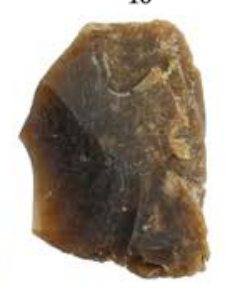

21

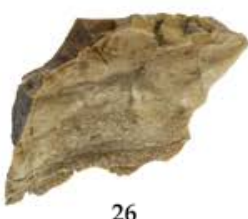

26

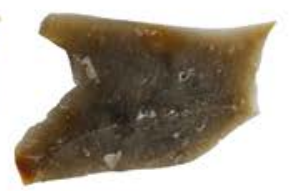

31

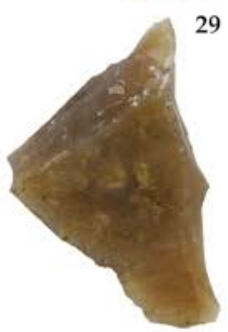

34

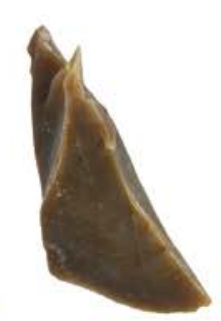

35
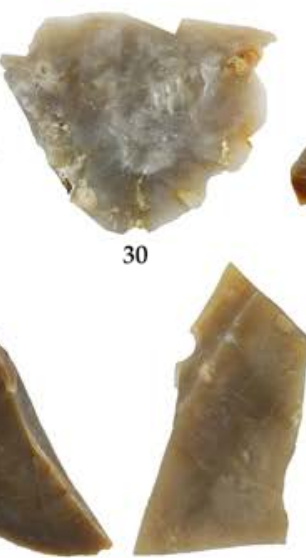

36

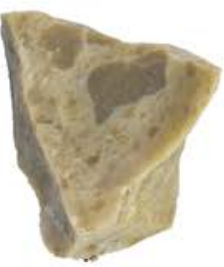

37

Fig. 12. Photos of the flints samples from geological outcrops analyzed in this study. Photo by F. Surmely. 


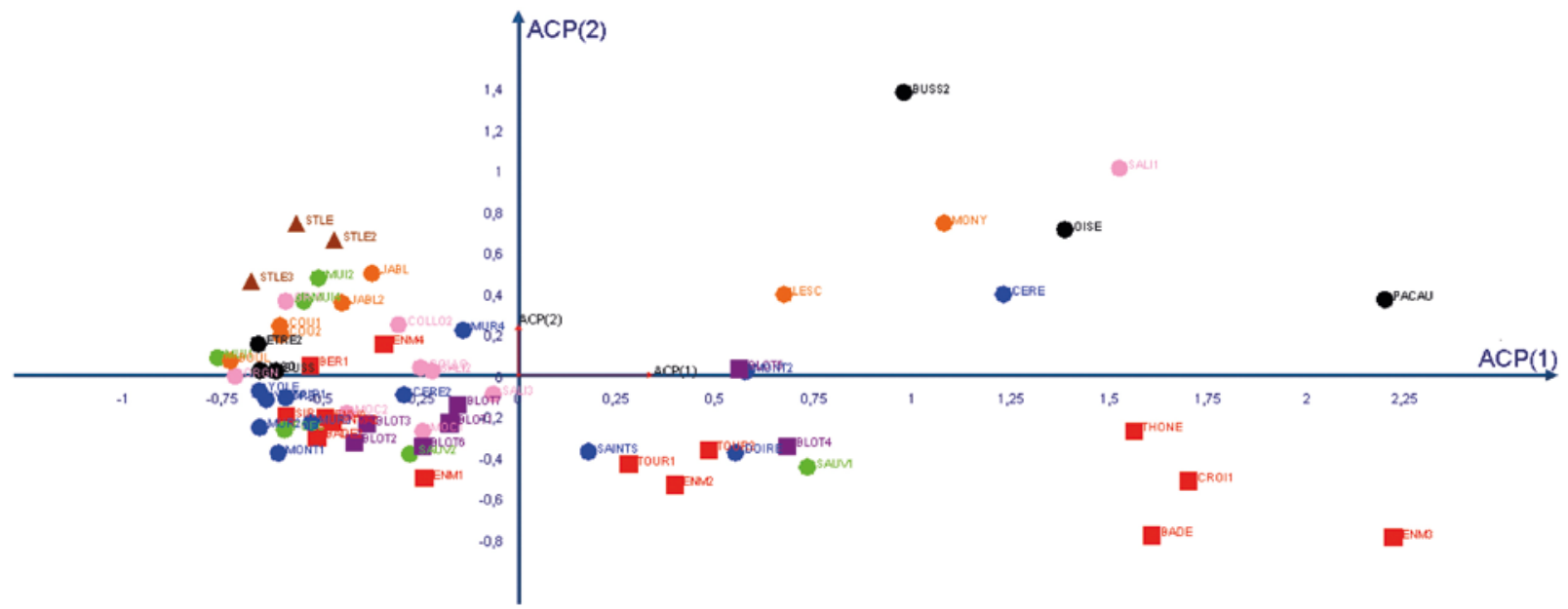

Fig. 13. PCA graph for ICP/MS data including the archaeological samples (squares) and the geological outcrops (circles). Purple square: Le Blot site; Red square: other archaeological sites; Blue circle: Cantal (Aurillac/Mur-de-Barrez basin); pink circle: southern outcrops (Ardèche, Gard and Drôme); orange circle: outcrops at Seine-et-Marne and Oise; green circle: outcrops at Cher and Loir-et-Cher; brown triangle: outcrops of Saint-Léger-du-Malzieu (Lozère); black circle: other outcrops. Drawing by F. Surmely.

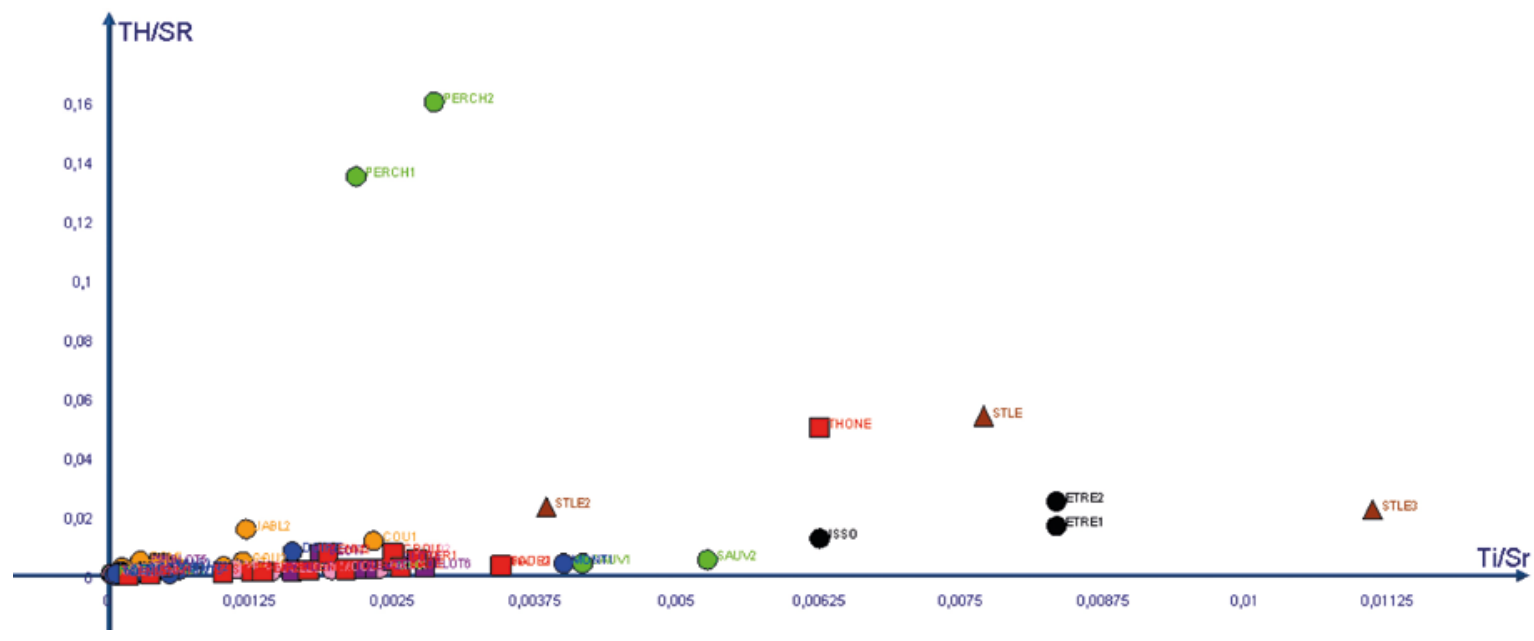

Fig. 14. Scatter plot with ICP/MS data concerning Log Th/Sr vs Ti/Sr and including the archaeological samples (squares) and the geological outcrops (circles). Purple square: Le Blot site; Red square: other archaeological sites; Blue circle: Cantal (Aurillac/Murde-Barrez basin); pink circle: southern outcrops (Ardèche, Gard and Drôme); orange circle: outcrops of Seine-et-Marne and Oise; green circle: outcrops of Cher and Loir-et-Cher; brown triangle: outcrops of Saint-Léger-du-Malzieu (Lozère); black circle: other outcrops. Drawing by F. Surmely and J.-B. Chalin.

France, Cantal being represented by only one sample. The results were mixed, but mainly allowed the exclusion of potential provenances.

To overcome this, an effort has been made to bring the sites and artefacts together in order to ensure the best representativeness of the geological reference corpus within the limits of the financial potential. The geographical field is very wide, encompassing a large part of France, from the Marne department to the Gard department, and including most of the large French sedimentary basins (Paris, Cantal, and Gard; Figs. 11, 12), which allowed surveys carried out earlier 


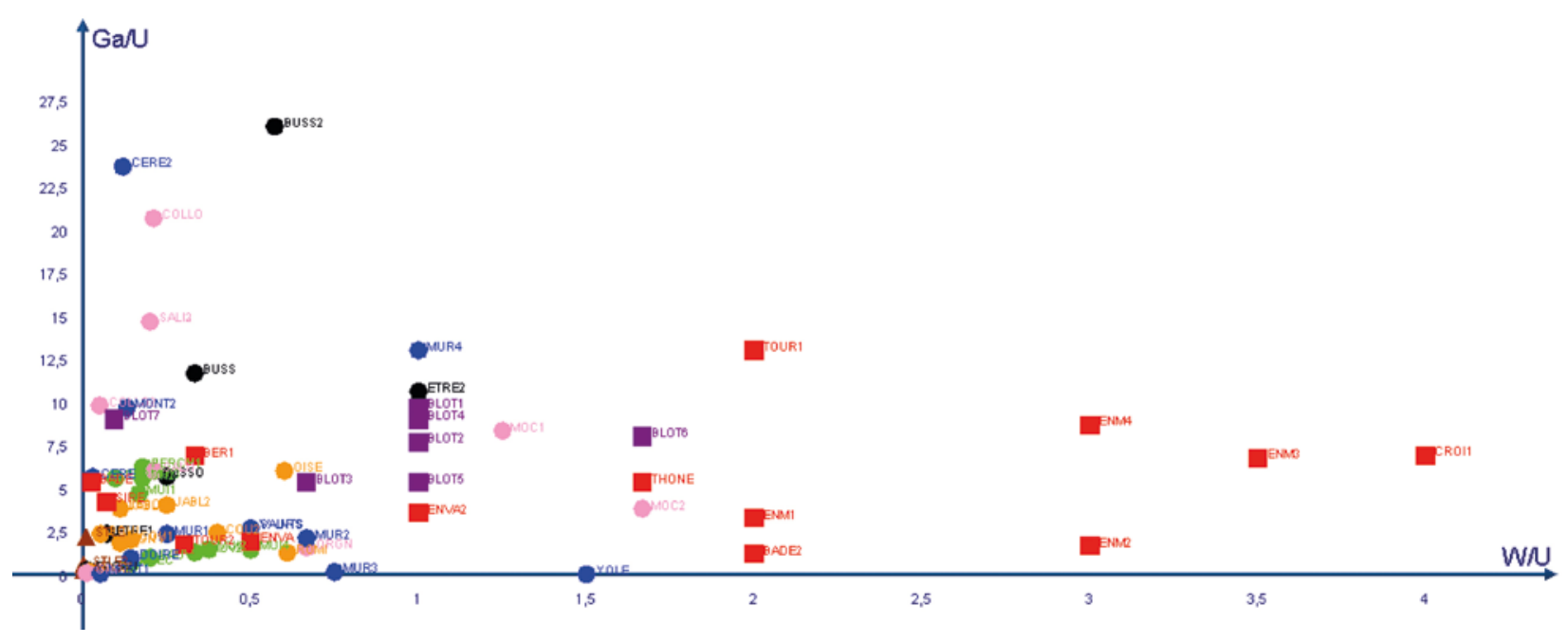

Fig. 15. Scatter plot with ICP/MS data concerning Log Ga/U vs W/U and including the archaeological samples (squares) and the geological outcrops (circles). Purple square: Le Blot site; Red square: other archaeological sites; Blue circle: Cantal (Aurillac/Murde-Barrez basin); pink circle: southern outcrops (Ardèche, Gard and Drôme); orange circle: outcrops of Seine-et-Marne and Oise; green circle: outcrops at Cher and Loir-et-Cher; brown triangle: outcrops of Saint-Léger-du-Malzieu (Lozère); black circle: other outcrops. Drawing by F. Surmely and J.-B. Chalin.

in several sectors to be used: Cantal (1993-1998), Paris (2000), Centre region (2005-2006), Nièvre (2008-2009), and Gard (2020) as well as the use of the holdings of the Lithotheque (Library of Geological Specimens) of the Orgnac Museum (Ardèche). An attempt was made to address the variability of the materials accessible to prehistoric populations by selecting several samples of different types.

The samples were prepared by employing the same operating mode (grinding, etc.) before the ICP/ MS analysis.

Analyzing the results is complex. It is about selecting elements or the relationships among them, both significant and discriminating. The choice of Sanchez de la Torre et al. (2020) was followed in favoring the following ratios: $\mathrm{W} / \mathrm{U} / \mathrm{Ga} / \mathrm{U}$ and $\mathrm{Th} /$ $\mathrm{Sr} / \mathrm{Ti} / \mathrm{Sr}$ while adding $\mathrm{Ce} / \mathrm{Cs} / \mathrm{Nb} / \mathrm{Cs}$ and a global analysis PCA.

\section{Results}

The results are complex. The PCA does not add much (Fig. 13) because it shows a wide dispersion of all the materials and does not allow any real differentiation between the geographical sectors, except that of Pacaudière (42; sample PACAU), which, unfortunately, is represented by a single sample. The $\mathrm{Th} / \mathrm{Sr}$ vs $\mathrm{Ti} / \mathrm{Sr}$ ratio is more interesting because it reveals an individualization of several other small basins, such as La Perche (samples PERCH1 and PERCH2), Les Étrelles (samples ETRE1 and ETRE2), Saint-Léger-du-Malzieu (samples STLE, STLE2 and STLE3), and Puy d'Issolud (ISSO), without any correspondence to the artefacts, except perhaps Thônes (Fig. 14).

The ratios $\mathrm{W} / \mathrm{U}$ vs $\mathrm{Ga} / \mathrm{U}$ (Fig. 15) and $\mathrm{Nb} / \mathrm{Cs}$ vs Ce/Cs (Fig. 16) allow a conclusion to be drawn, and most importantly reveal a distinction between the deposits in the south of Ardèche and the northeast of Gard on the one hand and other deposits in the central part of Gard (Salinelles, Collorgues) on the other.

No internal differentiation can be made within the vast Aurillac/Mur-de-Barrez basin and the materials of this basin cannot be distinguished from those coming from the south of the Massif Central. Therefore, it is not possible to distinguish the flint 


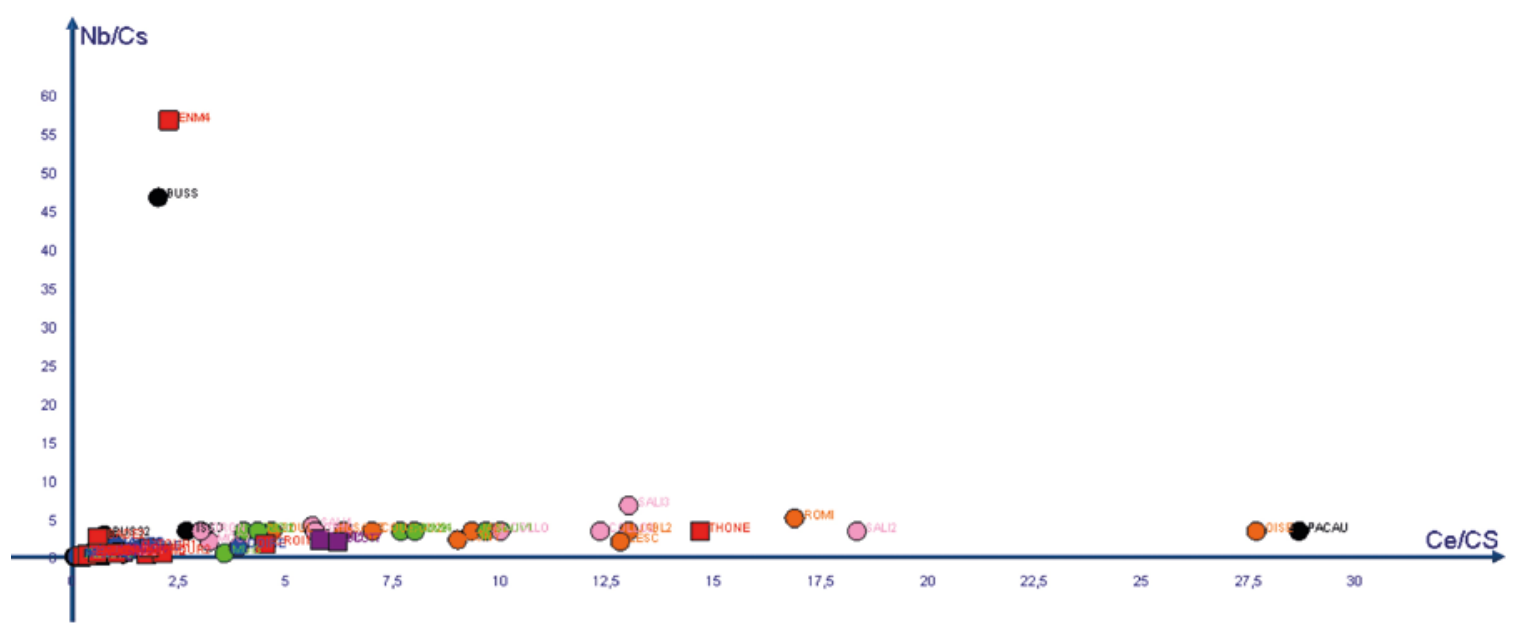

Fig. 16. Scatter plot with ICP/MS data concerning Log Nb/Cs vs Ce/Cs and including the archaeological samples (squares) and the geological outcrops (circles). Purple square: Le Blot site; Red square: other archaeological sites; Blue circle: Cantal (Aurillac/ Mur-de-Barrez basin); pink circle: southern outcrops (Ardèche, Gard and Drôme); orange circle: outcrops of Seine-et-Marne and Oise; green circle: outcrops of Cher and Loir-et-Cher; brown triangle: outcrops of Saint-Léger-du-Malzieu (Lozère); black circle: other outcrops. Drawing by F. Surmely and J.-B. Chalin.

from the Neolithic mining at Taussac from other flint from the Aurillac/Mur-de-Barrès basin.

The analysis of prehistoric artefacts shows that many of them are without possible correspondence to the analysed geological samples, such as those from Les Bughes, le Croizet, le Sire, la Bade, and Enval (certain pieces).

The Enval site is characterized by a major part of the samples having no correspondence to the analysed geological sites and a large range of samples displaying multiple origin possibilities.

The samples from the le Blot site are divided into two parts. Samples 1, 2, 3, 6, and 7 can be linked to flint from the southern part of the Massif Central, specifically from Montclus (Gard), while samples 5 and 6 probably originated in another area, perhaps Cantal.

\section{DISCUSSION AND PERSPECTIVES}

This study confirms the conclusion of previous studies: a geochemical study does not provide a full answer to the question of the geographical origin of Tertiary flints. This is explained by similarities in chemical composition of flint from different regions, but also by the nature of the geological corpus; too small to encompass the lateral and stratigraphic variability of the silicifications of each sector on the one hand and offers no real statistical value on the other. A geochemical study makes it possible to characterize small sedimentary basins but is insufficient in the case of larger and richer silicification areas.

However, the analyses do supply additional important informations, that cannot be provided by "classical" macroscopic and microscopic analyses.

Thus the origin of the Tertiary artefacts of le Blot, which, as is known, comprise the majority of this Magdalenian site, could be the sector of the south of Ardèche / North Gard, where silicifications are abundant and of very good quality. The vast majority of the analysed artefacts, especially those from the Magdalenian site of Enval, do not correspond with the analysed geological samples. The previous geochemical study reached this same conclusion (Dufresne 1999). It must therefore be assumed that 
their source was located either outside the sectors included in this geological reference system or in other levels of these same sectors.

The study also made the characterization of several small sedimentary basins possible, which could be very useful to researchers interested in the question of the diffusion of flint from these areas.

Progress requires broadening the geological reference corpus, integrating, in whole or in part, other Tertiary sedimentary basins not yet included (Apt-Forcalquier basin, Ebro valley, Tarn, etc.), and completing the range of samples taken from each sedimentary basin. This will be the aim of my future work.

It would also be good to set up a general database that would collect all the data acquired by researchers and would be accessible to all.

\section{Acknowledgement}

The research leading to these results received funding from the Cantal department.

I would like to thank all the people who contributed to this study: Jean-Baptiste Chalin (statistical analysis), Pascal Barrier (microfaciological analyses), Françoise Prudhomme, Nicolas Naudinot, Jean-Philippe and Annie Usse, Franz Boichut and Christophe Cupillard (sampling), Claire Sneeden and Jay Franklin (translation) and Agnè Čivilytė.

\section{REFERENCES}

Barrier, P., 1995. Expertise microfaciologique de silex d'intérêt archéologique (SRA Auvergne). Rapport REIG-IGAL, service régional de l'archéologie d'Auvergne, 13 p., 17 pl., dact.

Blet, M., Binder, D., Gratuze, B., 2000. Essais de caractérisation des silex bédouliens provençaux par analyse chimique élémentaire. Revue d'Archéométrie, 24, 149-167.

Bostyn, F., Lanchon, Y., 1992, dir. Jablines, Le Haut Château (Seine-et-Marne): une minière de silex au Néolithique (=Documents d'Archéologie Française 35). Paris: Maison des Sciences de l'Homme.

Bressy, C., 2002. Caractérisation et gestion du silex des sites mésolithiques et néolithiques du NordOuest de l'arc alpin: une approche pétrographique et géochimique. Préhistoires méditerranéennes, 231-235.

Bressy, C., 2006. Caractérisation géochimique des silex tertiaires: contribution à l'identification des matières premières diffusées au Néolithique final. In: Vaquer, J., Briois, F., dir. La Fin de l'âge de Pierre en Europe du Sud, Actes de la table ronde de l'EHESS, Carcassonne, 5-6 sept. 2003. Toulouse, ed. AEP, 221-231.

Cupillard, C., Affolter, J., Campy, M., Contini, D., Richard, H., 1995. La minière de silex néolithique de Blanc-Saule à Étrelles-et-la-Montbleuse (70) et l'exploitation du silex lacustre oligocène inférieur de Haute-Saône durant le Néolithique. Les Mines de silex au Néolithique en Europe, Editions du C.T.H.S., 179-240.

Delcourt-Vlaeminck, M., 1998. Le GrandPressigny dans le Nord-Ouest de l'Europe: le silex tertiaire, concurrent possible du Grand-Pressigny? In: Duhamel, P., dir. Impacts interculturelles au néolithique moyen. Du terroir au territoire: Sociétés et espaces. Suppléments à la Revue archéologique de l'Est. Dijon, 239-250.

Dufresne, N., 1998. Les silex de la Comté. Etude géologique. Mémoire de maîtrise. Université de Clermont 2, dact.

Dufresne, N., 1999. La discrimination des silex tertiaires auvergnats: étude géologique et application archéologique (magdalénien). Mémoire de DESS de l'université de Dijon, 87 p., dact.

Giez, S., 2001. Recherche sur l'origine des silex archéologiques d'Auvergne: comparaison avec des silex du Bassin de Paris. Mémoire de maitrise de l'université Blaise Pascal de Clermont.

Giligny, F., Bostyn, F., 2016. La hache de silex dans le Val de Seine:production et diffusion des haches au Néolithique. Sidestone Press. 
Lozouet, P., 2012. Stratotype Stampien. Paris: Biotope éditions.

Pasty, J.F., Surmely, F., Tzortzis, S., 1999. Contribution à un inventaire des ressources en silex: le département du Cantal (Massif Central, France). Bulletin de la Société Préhistorique Française, 96 (1), 7-13.

Remirecourt, M., Vaquer, J., 2017. Exploitations minières et productions de lames en silex de Mur-deBarrez (Aveyron), à la fin du Néolithique: un bilan des connaissances. Cahier d'Archéologie Aveyronnaise, 27-55.

Renault, S., 2006. La production de grandes lames au Néolithique final en Provence: matériaux exploités, multiplicité des productions, aspects technologiques et chrono-culturels, In: Vaquer, J., Briois, F., dir. La fin de l'Âge de Pierre en Europe du Sud: matériaux et productions lithiques taillées remarquables dans le Néolithique et le Chalcolithique du Sud de l'Europe, Actes de la table ronde de l'EHESS, Carcassonne, 5-6 sept. 2003. Toulouse, éd. AEP, 139-165.

Sanches De La Torre, M., Utrilla, P., Domingo, R., Jimenez, L., Le Bourdonnec, F. X., Gratuze, B., 2020. Lithic raw material procurement at the Chaves cave (Huesca, Spain): A geochemical approach to defining Palaeolithic human mobility. Geoarchaeology, 35 (6), 856-870. https://doi.org/10.1002/gea.21808.

Surmely, F., dir., 2003. Le site mésolithique des Baraquettes et le peuplement de la moyenne montagne cantalienne, des origines à la fin du Mésolithique. Mémoire de la Société préhistorique française, 32.
Surmely, F., 2008. La diffusion des silex crétacés dans le centre du Massif central durant la préhistoire (Paléolithique, Mésolithique, Néolithique). Paléo, 20, 115-144.

Surmely, F., Murat, R., 2003. Études comparatives sur la résistance mécanique de divers silex lacustres et marins français. Actes de la table ronde internationale d'Aurillac "les matières premières lithiques en préhistoire". Supplément à Préhistoire du Sud-Ouest, 337-342.

Surmely, F., Pasty, J.F., 2003. Les importations de silex en Auvergne durant la préhistoire. Actes de la Table ronde internationale d'Aurillac "les matières premières lithiques en préhistoire". Supplément à Préhistoire du Sud-Ouest, 327-336.

Surmely, F., Santallier, D., 2003. Les silex de la Côte Blanche et les métadolérites du secteur d'Entraygues (Aveyron). Compte rendu de l'excursion du 22 juin 2002. Actes de la Table ronde internationale d'Aurillac "les matières premières lithiques en préhistoire". Supplément à Préhistoire du Sud-Ouest, 367-372.

Vaquer, J., Gandelin, M., Briois, F., Montécinos, A., Ambert, P., 2006. Les industries lithiques en silex allochtones de la grotte Tournié (Pardailhan, Hérault). In: Vaquer, J., Briois, F., dir. La fin de l'Âge de Pierre en Europe du Sud: matériaux et productions lithiques taillées remarquables dans le Néolithique et le Chalcolithique du Sud de l'Europe, Actes de la table ronde de l'EHESS, Carcassonne, 5-6 sept. 2003, Toulouse, éd. AEP, 205-219. 


\title{
TERCIARO TITNAGO PRANCŪZIJOS TERITORIJOJE CHARAKTERIZAVIMAS NAUDOJANT GEOCHEMINI METODĄ
}

\author{
Frédéric Surmely
}

\section{Santrauka}

Atliekant aprašomą tyrimą buvo patvirtinta per ankstesnius tyrimus padaryta išvada, jog geocheminè analizè nesuteikia galimybės tiksliai nustatyti geografinès terciaro titnago žaliavos kilmès. Tai paaiškinama ne tik skirtinguose regionuose randamo titnago cheminès sudèties panašumu, bet ir ribotu geologinių duomenų rinkiniu. Jis visų pirma yra per mažas, kad apimtų horizontalią ir stratigrafinę silicifikuotų uolienų ịvairovę kiekviename sektoriuje. Antra, jis visai neturi reikšmès statistikai. Geocheminès analizès duomenys leidžia apibūdinti nedidelius sedimentacinius baseinus, tačiau jų nepakanka žaliavos šaltiniams, esantiems didesnèse ir didesne vidine ịvairove pasižyminčiose uolienų silicifikacijos zonose, nustatyti. Kita vertus, geocheminès analizès duomenys suteikia svarbios papildomos informacijos, kurios nebūtų galima gauti titnago žaliavas tiriant „klasikiniais“ makro- ir mikroskopiniu būdais.

Le Blot stovyklavietejje aptikti iš terciaro titnago pagaminti dirbiniai, kurie sudaro didžiąją šioje Madleno laikotarpio stovyklavieteje aptiktų dirbinių dalị, galèjo būti gaminami iš pietų Ardešo - šiaurès Garo sektoriuje randamo titnago, kuris pasižymi gausumu ir labai gera kokybe. Tačiau absoliučios daugumos ištirtų artefaktų geocheminiai duomenys nesutampa su geologinių méginių analizių duomenimis - tai ypač būdinga Madleno laikotarpio Enval stovyklavietei. Anksčiau tyrimus atlikę mokslininkai buvo paskelbę tokią pačią išvadą (Dufresne 1999). Remiantis šiais rezultatais reikia manyti, jog žaliavos, iš kurios pagaminti minèti titnago dirbiniai, šaltinis yra arba ne i palyginamąji geologinių duomenų rinkinị ittrauktuose sektoriuose, arba kituose tų pačių sektorių lygiuose.
Atlikus tyrimą taip pat pavyko apibūdinti kelis nedidelius sedimentacinius baseinus. Šie rezultatai gali būti naudingi mokslininkams, tiriantiems iš tokiuose baseinuose susiformavusio titnago pagamintų dirbinių paplitimo klausimus.

Siekiant postūmio ateities tyrimuose reikètų išplèsti geologinių duomenų rinkinị, ị jị ịtraukiant visus ar dalị kitų, iki šiol netirtų terciaro sedimentacinių baseinų Apt-Forcalquier baseinas, Ebro, Tarno upių slèniai ir kt.) bei ištirti papildomus mėginius, kurie atskleistų vidinę kiekvieno sedimentacinio baseino įvairovę. Šio tikslo autorius sieks ateities darbuose. Atliekant tokio pobūdžio tyrimus, būtų itin naudinga sukurti bendrą ir visiems prieinamą duomenyną, kuriame būtų surinkti visi mokslininkų sukaupti duomenys.

\section{ILIUSTRACIJŲ SĄRAŠAS}

1 pav. Skirtingo terciaro titnago, surinkto aliuvinėse upelio nuosedose centrineje Aurillac/Murde-Barrez baseino dalyje, Giou-de-Mamou vietovèje, pavyzdžiai. F. Surmely nuotr.

2 pav. Spalvų ir tekstūrų ìvairovè terciaro titnago gniutule iš Vézac vietovès (Kantalio departamentas, Aurillac/Mur-de-Barrez baseinas). F. Surmely nuotr.

3 pav. Silicifikuotų uolienų iš La Perche (Šero departamentas) įvairovè. F. Surmely nuotr.

4 pav. Titnagas iš Lasmolineries upelio (Thiézac vietovè, Kantalio departamentas) rytinèje Aurillac/ Mur-de-Barrez baseino dalyje. F. Surmely nuotr.

5 pav. Du smulkiai juostuoto, panašios išvaizdos titnago pavyzdžiai: kairèje titnagas iš Salinelles 
(Garo departamentas), dešinèje - iš Orgnac (Ardešo departamentas). F. Surmely nuotr.

6 pav. Žaliadumblio (Characeae) stiebelis ir ląstelè (oogonija) gabale terciaro titnago. P. Barrier nuotr. ir analizé.

7 pav. Iš atvežtinio terciaro titnago pagaminti dirbiniai, aptikti US80 lygyje Enval-Moliard stovyklavietëje (vidurinis Madlenas; Vic-le-Comte, Prancūzija; F. Surmely kasinejjimai). F. Surmely nuotr.

8 pav. Gaminių iš vietinio ir atvežtinio terciaro titnago pasiskirstymas pagrindinèse technologinèse kategorijose Enval stovyklavieteje (Madleno laikotarpis). Sud. F. Surmely.

9 pav. Iš terciaro titnago pagaminti titnago dirbiniai, rasti Le Blot stovyklavieteje (vidurinis Madlenas, Delporte kasinejjimai). F. Surmely nuotr.

10 pav. Akmens industrijos gaminiai iš terciaro titnago, Les Bughes stovyklavietė (Azilio laikotarpis, La Tour d'Auvergne vietové; F. Surmely kasinèjimai). F. Surmely nuotr.

11 pav. Situacinis straipsnyje analizuojamų žaliavų ir archeologinių radinių žemèlapis. F. Surmely brëž.
12 pav. Geologinèse atodangose surinkti ir šiame straipsnyje analizuojami titnago mèginiai. F. Surmely nuotr.

13 pav. Pagrindinių komponenčių analizès (PKA) diagrama, sudaryta pagal induktyviai susietos plazmos masių spektrometrijos (ICP-MS) duomenis. Kvadratais žymimi archeologiniai, skrituliais - geologinių atodangų mėginiai. F. Surmely brèž.

14 pav. Sklaidos diagrama su Log Th/Sr ir Ti/Sr santykio vertemis pagal ICP-MS duomenis. Kvadratais žymimi archeologiniai, skrituliais - geologinių atodangų mėginiai. F. Surmely and J.-B. Chalin brèž.

15 pav. Sklaidos diagrama su Log Ga/U ir $\mathrm{W} / \mathrm{U}$ santykio vertemis pagal ICP-MS duomenis. Kvadratais žymimi archeologiniai, skrituliais geologinių atodangų mėginiai. F. Surmely ir J.B. Chalin brëž.

16 pav. Sklaidos diagrama su Log $\mathrm{Nb} / \mathrm{Cs}$ ir Ce/Cs santykio vertemis pagal ICP-MS duomenis. Kvadratais žymimi archeologiniai, skrituliais - geologinių atodangų mėginiai. F. Surmely ir J.-B. Chalin brëž. 